\title{
Laurel Phillipson, Using Stone Tools: the Evidence from Aksum, Ethiopia
}

\author{
Cambridge Monographs in African Archaeology 77, \\ Archaeopress, Oxford, 2009, 149 pp, ISBN 9781407304083
}

\author{
Matthew C. Curtis
}

Published online: 2 July 2010

C The Author(s) 2010. This article is published with open access at Springerlink.com

This volume focuses on flaked lithic tools from surface collections and excavated assemblages in the Aksum area in Tigray, northern Ethiopia. The study reported in the volume concerns descriptions of lithic material documented as part of several archaeological surveys carried out by the author and colleagues over more than a decade and from a number of surface collections and excavation assemblages from Bieta Giyorgis Hill, surveyed and excavated by a Boston University and University of Naples 'l'Orientale' project. The volume does not cover in detail excavated lithic material from the 1993-1997 excavations at Aksum sponsored by the British Institute in Eastern Africa (BIEA), as this material has been published elsewhere, and does not consider ground stone artifacts. Even without detailed consideration of the 1993-1997 BIEA lithic and ground stone material, the volume presents important insights into the production of lithic tools during the rise and development of sociopolitical complexity in the region between the early first millennium BC and late first millennium AD. While this time period, traditionally encompassing the PreAksumite to early Post-Aksumite periods, is arguably the best studied period in the Holocene archaeology of the Horn of Africa, and the Aksum area is the most closely investigated region in Ethiopia, relatively little attention has been given over the years to the ways that flaked lithic artifacts were produced, utilized, and incorporated into local and regional economies and cultures of the Aksum area and wider highlands of the northern Horn. Therefore, the volume under review provides a most welcome contribution to an under-published and under-analyzed aspect of the region's archaeology.

The volume includes six chapters, several simple maps, dozens of drawn lithic illustrations, a short glossary of terms used, a bibliography, and a series of 15 plates containing close-up black and white photos of lithic forms and macroscopic wear on individual artifacts. Chapter 1 serves as a sort of preface and is guest-authored by Rodolfo Fattovich, providing a brief overview of research carried out in the Aksum

M. C. Curtis $(\bowtie)$

University of California, Santa Barbara, CA, USA

e-mail: matthew-curtis@sbcglobal.net 
area since the early 1990 s and a short summary of central elements concerning the archaeology and culture history of the Aksum region. Chapter 2, entitled 'The Area Surveyed, Acknowledgements, Problems and Approaches', is concerned primarily with the basic methodological and theoretical orientation of the study and places the reported work within the context of the history of archaeological research in the Aksum area. A significant portion of the chapter addresses inherent limitations concerning the use of surface-collected materials in defining lithic industries for the region, including such issues as problematic dating of surface materials and the presence of non-artifactual edge modification. Chapter 3, 'Surface Collections and Excavated Assemblages', makes up the bulk of the volume, occupying 90 of 149 pages. Chapter 3 presents descriptions of representative lithic material from individual sites (with site number and UTM coordinates listed) within 13 arbitrarily imposed geographical sectors utilized in the survey strategy. Qualitative descriptions of individual sites' lithic material are often detailed, sometimes providing discussion on individual artifacts that are representative of the larger collection, and almost always providing hand-drawn illustrations of representative artifacts and ample consideration of sites' area physiography, archaeological features, and associated material culture. Throughout, references are made to previous research on sites reported, attention is paid to the significance of lithic artifact types for the culture history of the region, and the author diligently relates individual archaeological sites to larger issues.

Chapter 4, 'Chronological Summary, discusses lithic manufacture and use in six sections: (1) 'The Earliest Evidence', (2) 'Pre-Aksumite Period circa 800/700-400 BC', (3) 'Proto-Aksumite Period circa 400-50 BC', (4) 'Early Aksumite Phase circa 50 BC-AD 150 and Classic Aksumite Phase circa AD 150 - 400/450', (5) 'Middle Aksumite Phase circa AD 400/450-550 and Late Aksumite Phase circa AD 550700', and (6) 'Post-Aksumite Period after circa AD 700'.Most of the discussion in Chapter 4 centers on qualitative overviews of characteristic knapping techniques and tool and core forms, from the Pre-Aksumite to Post-Aksumite periods. Chapter 5, 'Technical and Economic Evidence', provides extended overviews of a variety of lithic tool types, including pot decorators, quartz crystal knapping tools, scrapers, and small knives and cutting tools. This discussion is followed by suggestions for how lithic evidence might provide insights into ancient commerce and labor, and a short section on evidence for Aksumite gold and base metals production and use. Finally, Chapter 5 concludes with a consideration of the most common lithic raw material types from the survey area, including chert, chalcedony, quartz crystals, obsidian, and others. In the final chapter, Chapter 6, 'Patterns of Site Distribution and Areas for Future Research', the author identifies and discusses briefly four principal settlement patterns observed in the Aksum survey area. The chapter then concludes with suggestions on how future archaeological survey, excavation, and artifact analysis might improve our understanding of the region's lithic tool traditions and, thus, our understanding of ancient cultures and economies in the area.

The chief strength of the volume is its detailed qualitative descriptions of site areas and representative flaked lithic artifact forms and characteristics. The author must be commended for bringing together descriptions from a range of sites in the Aksum region and for demonstrating the significance of lithic tool production and use from the Pre-Aksumite to Post-Aksumite periods by outlining a number of ways 
in which the functions of these tools changed through time within the region's domestic economies. Phillipson mostly succeeds in producing a descriptive chronology of the forms of flaked lithic tools for the Aksum area. The volume's Chapter 3, an extended report on the study's lithic surface collections and excavated assemblages, is the heart of the monograph and its most important component. In describing this chapter, Phillipson states that:

It is intended that this section will stand as a permanent record of a major aspect of Aksumite and earlier material culture, to which other researchers may refer and which they may wish to incorporate into their own studies or to reinterpret now that most of the sites from which the material derived are no longer available for further study. (p. 3)

Indeed the author has succeeded in producing a record that systematically documents an important component of Aksum's cultural heritage and one that will likely become an indispensible account for cultural resource management and research in the region in the years to come.

Given its important contributions, the volume is limited by a lack of quantitative data and metrical analysis. Central to the problem of quantitative data is that the study presents data only for a relatively limited number of representative lithic artifacts from each site and these data are restricted to only the reporting of artifact maximum linear dimensions. The surface survey work on which much of the volume is based did not employ a surface collection sampling strategy beyond collecting representative examples from each site, so the presentation of metrical data is limited to the dimensions of a variable, and often small, number of lithic artifacts per site. While reference is made to such elements as site artifact surface scatter densities, artifact abrasion and patina, raw material type, raw material color, utilization damage, striking platform attributes, flake scarring, retouch, etc., none of these are presented with supporting metrical or non-metrical data. The paucity of quantitative data ultimately limits the power of the author's interpretations concerning changes in tool functions and frequency through time reported in Chapter 4 and technical aspects of production and use and socio-economic evidence reported in Chapter 5. For example, in discussing key aspects of the microlithic Pre-Aksumite tradition reported in the volume, the author states that:

A third significant feature of the microlithic Pre-Aksumite collections is their variability. Not only do they differ one from another in the range of materials used and in the core and artifact types produced and fineness of the workmanship, but where a sufficiently large collection has been recovered it can be seen that there is much variability and little or no standardization of the tool forms. (p. 110)

While there is no reason to challenge the veracity of the author's claim, the strength of this conclusion is compromised by the lack of data in support. There is little demonstration to the reader of this proposed variability, as there are no tables or other means of conveying data that might elucidate the variability in question. One of the central conclusions of the study is that flaked lithic artifacts have been found in greater quantities, but with less variability in form, on sites attributed to the Early and Classic Aksumite culture phases than to those of earlier phases. Phillipson 
contends that this may reflect population growth in the Aksum area and resulting changes in patterns of settlement. She goes on to state that during the Middle and Late Aksumite phases, "there was progressive reduction both in the numbers of sites where they were manufactured and used and in their range of forms, followed by the loss of technical accomplishment in the Post-Aksumite period" (p. 116). These are important observations that are supported in some regards by the qualitative descriptions of individual artifacts and sites provided in Chapter 3 and by the author's ability to convey important themes concerning the culture history of the region. However, they remain largely unsubstantiated for the reader since data from which the conclusions are drawn are not tabulated, making comparative perspectives problematic.

These limitations notwithstanding, this volume should be in the possession of anyone interested in the material culture of ancient Aksum. It is the best available account of lithics in the Aksum area and succeeds in suggesting the importance of lithic data for understanding economic and social organization in the Aksum area through time. The volume is the result of sustained, intensive archaeological survey work and the study of thousands of lithic artifacts, and it provides a well-written synthesis of flaked lithic artifact materials of the first millennium $\mathrm{BC}$ and first millennium $\mathrm{AD}$. The descriptions of individual sites and representative lithic artifacts are commendable and the final three chapters offer a number of compelling observations and suggestions for future research in the region.

Open Access This article is distributed under the terms of the Creative Commons Attribution Noncommercial License which permits any noncommercial use, distribution, and reproduction in any medium, provided the original author(s) and source are credited. 